\title{
Antimicrobial photodynamic therapy and its applicability in aquaculture sys- tems and aquatic animal health management: An overview
}

\author{
Pooja Kanyal ${ }^{1}$, Rameez Roshan P.M. ${ }^{2}$, Mohd Danish ${ }^{3}$, Anita ${ }^{4}$, Akansha khati ${ }^{5}$ and \\ R.S.Chauhan ${ }^{6 *}$
}

${ }^{1}$ Department of Aquatic Animal Health Management, Central Institute of Fisheries Education, Mumbai- 400 060, INDIA.

${ }^{2}$ Department of Fish Genetics and Breeding, Central Institute of Fisheries Education, Mumbai- 400 060, INDIA.

${ }^{3}$ Department of Fisheries Resource Management, College of Fisheries, G. B. Pant University of Agriculture \& Technology, Pantnagar-263145 (Uttarakhand), INDIA

${ }^{4,5,6}$ Department of Aquaculture, College of Fisheries, G. B. Pant University of Agriculture \& Technology, Pantnagar263145 (Uttarakhand), INDIA

*Corresponding author. E-mail: rikhi812chauhan@gmail.com

Received: August 7, 2015; Revised received: February 13, 2016; Accepted: March 18, 2016

\begin{abstract}
Global aquaculture production in 2012 touched new high of 90.4 million tonnes including 66.6 million tonnes of food fish and 23.8 million tonnes of aquatic algae providing $19.2 \mathrm{~kg}$ per capita food fish suppy. Aquaculture is reported to suffer heavy production and financial losses due to fish infections caused by microbial pathogens. Therefore in order to make aquaculture industry more sustainable, effective strategies to control fish infections are urgently needed. Antimicrobial Photodynamic Therapy (aPDT) is an emerging, low-cost anti-microbial approach to the treatment of locally occurring infections and also for the treatment of aquaculture water and waste waters. Already proven effective in various medical and clinical applications, it utilizes three vital components: a photosensitizing agent (PS), a light source of an appropriate wave length and oxygen. aPDT has got a potential of being a preferred choice over antibiotics in aquaculture systems because of its non-target specificity, few side effects, lack of the pathogenicity reversal and re-growth of the micro-organism after treatment and the lack of development of resistance mechanisms. The technique has been proved effective in vitro against bacteria (including drug-resistant strains), yeasts, fungi, viruses, parasites and even the stubborn biofilms. Although preliminary results indicate that this technology has a high potential to disinfect waters in aquaculture system and also in hatcheries and seed production units, but it clearly needs more deep knowledge and multi-dimenstional approach.
\end{abstract}

Keywords: Antibiotic resistance, Antimicrobial photodynamic therapy, Fish farming, Photosensitizer

\section{INTRODUCTION}

Fish diseases affect the survival rate and growth of fish. Expensive drug treatments in aquaculture system contribute to higher cost as well as deterioration of environment. Control of infections is difficult in fish farming conditions (Defoirdt et al., 2007). Poor water quality, ubiquitous nature and rapid spreading of pathogens, environmental adverse conditions, high stocking densities, different stages of the fish life cycle, resistance in common pathogenic bacteria, low activity of chemotherapeutic agents against bacterial endospores and fungal zoospores, and few drugs licensed for fishery use are factors that make disease prevention difficult in aquaculture (Almeida et al., 2009). In the same context Antimicrobial Photodynamic Therapy (aPDT) also known as Photodynamic Chemotherapy (PACT) is a recent advanced non-antibiotic approach receiving considerable attention for its potentialities as a new form of antimicrobial treatment (Alves et al., 2011; Benov, 2014; Jui -Teng, 2014). At the very beginning of its history, photodynamic approach was applied in medicine (1903) by Albert Jesionek and Hermann von Tappeiner for the treatment of patients with malignant skin lesions as referred by Lin Jui-Teng, 2014. Although, since the arrival of "the Golden Age of antibiotics" after the discovery of penicillin and massive production of antibiotics in the middle of last century, antimicrobial photosensitizing reactions were largely forgotten (Alves et al., 2009). Moreover, in the last decade huge rise in antibiotic resistance encountered which has driven a need of research to the development of new potent anti-microbial strategies. In the same context, this new methodology has already proved to be effective in vitro against bacteria, viruses, fungi and protozoa (Merchat et al., 1996; Bonnett, 2000; Jemli et 
al., 2002; Kosaka et al., 2007; Alves et al., 2008; Costa et al., 2008; Carvalho et al., 2009; Alves et al., 2009 and Alexandra et al., 2013) Different classes of molecules including phenothiazine, porphyrines, phthalocyanines and fullerenes have demonstrated antimicrobial efficacy against a broad spectrum of antibiotic resistant microorganisms upon illumination. In aPDT, the administered photosensitizing compound selectively accumulates in the target cells which on local illumination with a certain light wavelength in presence of molecular oxygen give rise to the formation of toxic oxygen radicals to destroy the microbes non- specifically. Recent studies, in particular, have demonstrated that aPDT can be effective in the selective inactivation of microorganisms and it can become a potential alternative for the treatment and eradication of microbial infections (Hamblin and Hasan, 2004; O'Riordan et al., 2005). Lin Jui-Teng in the year 2014 performed a comprehensive analysis for aPDT in aquaculture systems. To implement this technology in the environment, some additional aspects less relevant to aPDT in the clinic area needs to be considered, namely: 1) the removal of the sensitizer after photodynamic action to avoid the release of the PS to the water output; 2) the determination of the stability of the PS conjugates under sunlight irradiation conditions; 3) the assessment of the impact of this procedure on the natural non-photogenic microbial community structure, for instance when this technology is applied in extensive and semi- intensive fish farming systems; 4) the toxicity of the PS on aquatic organisms (e.g. fish and shellfish) at doses which induce marked mortality of microbial pathogens; 5) the effect of physical and chemical properties of environmental waters on aPDT; 6) the possibility of using natural sunlight as light source; 7) the efficacy of the porphyrin derivatives relatively to that of other PS in aPDT. Effectiveness of photodynamic inactivation has been evaluated for the destruction of faecal bacteria (Wolfsen and Wang, 1993, Konig et al., 2000, Smith et al., 2002, Chen-Collins et al., 2003; Akilov et al., 2007; viruses (Wilder-) and helminthes eggs (Ganz et al., 2005) in nature waters. Studies showed that cell cultures of gram-positive bacteria (e.g. meticillinresistant $S$. aureus), gram-negative bacteria (e.g. E. coli), fungi (e.g. C. albicans) and fungal-like pathogens (e.g. Saprolegnia spp.) and parasitic protozoa (e.g. Acanthamoeba palestinensis) in the presence of micromolar PS doses (Schleier et al., 2004). Antimicrobial photodynamic therapy (aPDT) is based on the concept that a photosensitizer (PS) should be preferentially localized in the pathogens and not in the surrounding tissue, and subsequently activated by visible light of the appropriate wavelength to generate reactive oxygen species (ROS) in presence of oxygen that are cytotoxic to the pathogens. The significance of study lies in the fact that aPDT should be delivered to the various stakeholders in aquaculture industry as it is effective in the selective inactivation of microorganisms. In general, all organisms namely viruses, bacteria, protista, yeasts, algae, insects and cultured mammalian cells are sensitive to inactivation by the photodynamic effect (Wainwright, 1998; Makowski and Wardas, 2001; Lukšiene, 2005). The effects of aPDT on microorganisms depend on at least four factors: the concentration of the dye, the concentration of molecular oxygen and the appropriate wavelength and intensity of light (Capella and Capella, 2003). Increasing the concentration of a sensitizer at a fixed light dose leads to increased viral inactivation (Kasturi and Platz, 1992). Efficacy and the production rate of reactive oxygen species was found to be proportional to the PS (MB) concentration and the initial light intensity resulting into decreasing function of the light illumination time due to the depletion of PS concentration (Jui-Teng Lin, 2014). Dissolved oxygen concentration in water plays an important role in the production of the oxidative species required for the photodisinfection process (Alouini and Jemli, 2001). A very wide selection of light sources is available, ranging from basic tungstenfilament lamps to laser technology. However, aPDT uses low-power light rather than the lasers used in ablative therapy as microbial killing is attained with milliwatts rather than tens (or hundreds) of watts (Wainwright, 1998). In terms of molecular structure, molecular charge is important in determining antiviral activity. Thus, it is more likely that positively charged photosensitizers will be effective in causing nucleic acid damage than will neutral or anionic congeners (Wainwright, 2004). The positive charges on the photosensitizer molecule appear to promote a tight electrostatic interaction with negatively charged sites at the outer surface of bacterial cells. This behaviour also appears to apply to nonenveloped viruses such as hepatitis A virus and bacteriophage MS2, whose viral capsids and proteins are negatively charged at physiological pH (Casteel et al., 2004). This kind of association increases the efficiency of the photoinactivation process (Casteel et al., 2004; Lazzeri et al., 2004). Efficiency of photodynamic inactivation of $V$. fischeri in-situ were found unaffected by the variation of $\mathrm{pH}$, temperature, salinity, or oxygen concentration within the characteristic ranges of aquaculture waters, although found to be affected by the content of the suspended solids in the medium, the concentration of PS and the light fluence rate (Alves et al., 2011). The objective of presenting this study is to collect and review information on Antimicrobial photodynamic therapy and present it before the academia, aquapreneurs, industry and other concerned users for its further study and application.

Photosensitizers (PS): A photosensitizer (PS) can be any natural or synthetic compound which undergoes excitation upon illumination to a certain wavelength of light, demonstrating antimicrobial efficiency against a broad spectrum of microorganisms. The photodynamic 
treatment efficiency of a PS depends on several factors like the presence or absence of charge, charge distribution and the presence of peripheral substituents. The parameters in the make-up of the photosensitizer include lipophilicity (relative solubilities in water and lipids), degree of ionization, electric charge, nonspecific protein binding (Maisch et al., 2004) and other factors, such as light absorption characteristics (the maximum wavelength of absorption and the intensity of the absorption) and the efficiency of formation of the triplet excited state or of singlet oxygen production and free radicals (Wainwright, 2000). Usually aromatic molecules have good light absorption capacity due to their ringed molecular structure and are efficient in the formation of long-lived triplet excited states, which in turn give rise to singlet oxygen (e.g., molecular oxygen) which are very reactive thus producing molecular consequences on important biological targets like plasma membrane, nucleic acids etc. For a compound to be considered as a PS for use in photodynamic treatment in an open system like a fish farm or hatchery system it must fulfill some properties which are application dependent viz. good absorption capacity at the wavelength of the spectral region, show good efficiency to generate singlet oxygen (De Rosa and Crutchley, 2002; Wainwright, 2007). Merchat et al., 1996; Minnock et al., 1996; Reddi et al., 2002 shows killing efficacy against a broad spectrum of multi drug resistant Gram-positive and Gram-negative bacteria upon irradiation with visible light. Alves et al., in the year 2009 reviewed photosensitizing properties of various organic dyes (such as rose bengal, eosin, and methylene blue), fullerenes, porphyrins (of natural and synthetic origin), phthalocyanines and related tetrapyrrolic macrocycles. Synthetic non-porphyrin compounds, like the phenothiazine dyes: methylene blue and toluidine blue (Kim et al., 2001; Maclean et al., 2008) organic chemical dyes belonging to furanocoumarins e.g. psoralen (Tanielian et al., 2001; Al-Rawahi et al., 2008) were also reported to have photosensitizing properties. Although no non-porphyrin sensitizer has been approved for PDT applications, a small number of anthraquinone, phenothiazine, xanthene, cyanine and curcuminoid sensitizers are under consideration and some are being evaluated in clinical trials (Ormond and Freeman, 2013).

Preffered PS in aquaculture setup: Porphyrins are a class of aromatic heterocyclic compounds that are largely ubiquitous in nature. Porphyrin derivatives which are used as photosensitizers can be natural porphyrins or chemically modified natural porphyrins. The second group is constituted only by synthetic porphyrins which can be neutral, cationic or anionic (Tang et al., 2007). Porphyrins and analogues have been the most promising compounds used in photochemotherapy in fish farming units (Milson et al., 1996), as they can utilize sun as light source since sunlight penetrates deeply into the water column resulting in a nearly uni- form illumination of large volumes of water, also it makes this approach more inexpensive. Moreover, the Soret absorption band of porphyrins in the 420-430nm spectral region allows a very efficient interaction with blue light wavelengths, resulting in maximum penetration into natural waters (Baker and Smith, 1982). Porphyrin derivatives show toxicity towards eukaryotic cells only at millimolar concentrations whereas microbial inactivation is effective at micromolar concentration (Jemli et al., 2002; Costa et al., 2008; Alves et al., 2009) suggesting their non-toxic property against higher organisms (as fishes) at photochemically active doses (namely, in the micromolar concentration range), also their excessive accumulation in the environment is unlikely because of their gradual photobleaching by solar light. The immobilization of the porphyrin is largely recommended as it allows PS recovery and reuse, avoiding the ingestion by fish and also the release into the open water.

PS administration: In clinical set-up photodynamic antimicrobial therapy for localized infections is carried out by local delivery of the PS into the infected area by several methods such as topical application, instillation, interstitial injection or aerosol delivery. While in case of internal or systemic infections, targeted photosensitizer delivery method is employed. Methods of targeting photosensitizers specifically to a certain type of microorganism include antibody conjugation (Tagmatarchis and Shinohara, 2001) attachment of polycationic peptides (Menezes et al., 1990) and employing bacteriophages (Dobson and Wilson, 1992). There is intensive research on particulate delivery systems, e.g. nanoparticles, polymers or liposomes which can incorporate lipophilic photosensitizers and show selectivity against tumour cells. Nanoparticles can be ideal carriers of photosensitizer molecules for the photodynamic effect (Wang et al., 2004). Use of solid nanoparticles consists of polymers, metals, and ceramics. Polymeric nanoparticles are typically biodegradable, like polylactide/polyglycolide copolymers (Konan et al., 2003). Gold nanoparticles having a high dye-loading capacity due to their small particle size (2 $-4 \mathrm{~nm}$ ) showed very good results in animal studies (Hone et al., 2002; Cheng et al., 2008). Roy et al in the year 2003 and Ohulchanskyy et al., in the year 2007, indivisually prepared organically modified mesoporous silica particles containing a photosensitizer.

PS localization: The main targets are the external microbial structures, like cell walls, cell membranes, protein capsids, lipid envelopes and nucleic acids. Because of the limited migration of $\mathrm{O}_{2}$ from the site of its formation (Moan and Berg, 1991) sites of the cell or tissue damage are closely related to the localization of the sensitizer (Peng et al., 1996). Selectivity with respect to space is noticed for many including lysyl chlorine which is highly selective for lysosomes, the monocationic porphyrin are for membranes and the porphycene monomer for mitochondria (Kessel et al., 1995). 
Sensitizers that localize in mitochondria, like Photofrin, or are produced in mitochondria, like 5aminolevulinic acid (ALA)-induced protoporphyrin IX, are likely to induce apoptosis, while sensitizers localized in the plasma membrane are likely to cause necrosis during light exposure. Aggregated as well as hydrophilic sensitizers are likely to be taken up by the cell and hence get localized onto the lysosomes or endosomes.Generation of reactive oxygen species (ROS) can follow two alternative pathways after illumination of a given photosensitizer. Upon absorption of a photon by the ground-state photosensitizer, the singlet excited state $1 \mathrm{PS}^{*}$ is formed. Excited 1PS* state is short-lived and can undergo intersystem crossing to a long-lived triplet state, or alternatively can return to the ground state by fluorescence emission and/or heat. Generally the triplet state acts as a mediator of type-I / type-II photosensitization processes. Type-I: Generation of hydrogen peroxide $\left(\mathrm{H}_{2} \mathrm{O}_{2}\right)$, hydroxyl radical (HO), and superoxide anion $\left(\mathrm{O}_{2}^{-}\right)$by charge transfer from excited PS. Type-II: The triplet state of 3PS* can undergo energy exchange directly with triplet groundstate oxygen, leading to the formation of singlet oxygen, $\mathrm{O}_{2}$. The generated ROS react rapidly with their environment depending on the localisation of the excited PS weather its bacteria cell wall, lipid membranes, peptides, or nucleic acid. Both reactions occur simultaneously and in competition.

Photo damage: Although antioxidant enzymes such as superoxide dismutase, catalase and peroxidase give protection against some ROS, they do not protect against singlet oxygen (Wainwright and Crossley, 2004) which, according to the literature, is the main ROS through which the PS exert their photo-dynamic action (Maclean et al., 2008). Moreover, singlet oxygen has been shown to inactivate these enzymes (Kim et al., 2001). The main targets of the antibacterial and antiviral photodynamic activity are the external microbial structures (Hamblin and Hasan, 2004; Zupan et al., 2008). The damages to the external microbial structures can involve leakage of cellular contents or inactivation of membrane transport systems and enzymes (Mettath et al., 1999). Some damages produced in the nucleic acid chain can be repaired by the action of DNA repairing systems (Schafer et al., 1998). It has been concluded that although nucleic acids damage occurs, it cannot be the principal cause of microbial photodynamic inactivation (Hamblin and Hasan, 2004; Durantini, 2006). Fungi present much more complex targets than bacteria where photo- inactivation seems to be less dependent on cell-bound PS and needs PS to reach sub-cellular targets such as the mitochondria (Bertoloni et al., 1987) or the nucleus (Kassab et al., 2003).aPDT damage is manifested as swelling (Moan et al., 1979), bleb formation (Moan et al., 1979; Volden et al., 1981), shedding of vesicles containing plasma membrane marker enzymes, cytosolic and lysosomal enzymes (Volden et al., 1981), reduction of active transport (Moan et al., 1983), depolarization of the plasma membrane (Specht and Rodgers, 1990), increased uptake of a photosensitizer (Moan and Christensen, 1981), increased permeability to chromate (Moan et al.,1983) and even to cytosolic enzymes like lactate dehydrogenase (Christensen et al.,1982), inhibition of the activities of plasma membrane enzymes such as $\mathrm{Na}^{+} \mathrm{K}^{+}$-adenosine triphosphatase (ATPase) and $\mathrm{Mg}^{2+}$-ATPase (Gibson et al., 1988), a rise in $\mathrm{Ca}^{2+}$ (Joshi et al., 1994), up- and down-regulation of surface antigens (Davies et al., 1986), lipid peroxidation (Thomas and Girotti, 1989), that may lead to protein crosslinking (Reyftman et al., 1986) and damage to multidrug transporters (Kessel et al., 1995). Photo activity could rapidly induce apoptosis, both in vitro (Agarwal et al., 1991;) and in vivo (Zaidi et al., 1993; Webber et al., 1996) by release of cytochrome c and other mitochondrial factors into the cytoplasm (Kluck et al., 1997).

\section{APPLICATIONS OF ANTIMICROBIAL PHOTO- DYNAMIC THERAPY IN FISHERIES AND AQUACULTURE}

Antibacterial photoinactivation: The major bacterial pathogens affecting various finfish are Gram -ve including Aeromonas hydrophila, A. salmonicida, Edwardsiella tarda, Vibrio anguillarum, Pseudomonas sp., Yersinia ruckeri, Flexibacter columnaris, Flavobacterium sp., Photobacterium damselae piscicida (formerly Pasteurella), P. damselae (formerly Vibrio damsela) however, only a few Gram +ve species affect finfish, such as Renibacterium salmoninarum, Nocardia spp., Mycobacterium sp., Streptococcus sp. (Shao, 2001; Toranzo et al., 2005; Meyer, 1991). The bacterias of public health significance that contaminate fish are classified into two broad groups the indigenous microflora (e.g., Vibrio anguillaru, V. vulnificus, Photobacterium damselae, A. hydrophila, A. salmonicida) and non-indigenous microflora (introduced through environmental contamination e.g. Enterobactereaceae such as Salmonella sp. and Escherichia coli) (Costa et al., 2008; Carvalho et al., 2009). Multiple antibiotic resistant (MAR) V. harveyi has been isolated from shrimp culture systems across Asia and Latin America. Tri- and tetracationic porphyrins, when irradiated by the appropriate light, can efficiently inactivate Gram (+) and Gram (-) faecal bacteria both when the PS are free or immobilized on solid matrixes (Alves et al., 2009). Ten bacterial species isolated from fish farming plants, namely $V$. anguilarum, $V$. parahaemolyticus, $P$. damselae subsp. damselae, $P$. damselae piscicida, A. salmonicida, E. coli, Enterobacter sp., S. aureus, E. faecalis, Pseudomonas sp. were successfully inactivated using aPDT methodology. In another study a cationic porphyrin Tri-Py+-Me -PF was found efficient against nine pathogenic bacteria isolated from a semi-intensive aquaculture system (Arrojado et al., 2011). Photodynamic therapy is found 
equally efficient in controlling the growth of multiple antibiotic resistant $V$. harveyi strain under both in vitro and in vivo conditions using $\mathrm{RB}$ as the photosensitizer on Artemia nauplii model (shrimp larviculture systems) (Ashok et al., 2012). The authors reported that PACT was effective in killing the pathogen under both in vitro and in vivo conditions without deleterious effects on Artemia nauplii.

Water disinfection: Water disinfection using PACT is a relatively recent concept. Rose Bengal was found effective in killing $99.99 \%$ of $E$. coli in a contaminated water sample when immobilized on poly (styrene) beads (Bezman et al., 1978). aPDT methodology has been successfully employed to disinfect wastewater in a small scale, using cationic porphyrin 20a and sunlight (Jemli et al., 2002). The photocatalytic method can also be applied for the degradation of toxins secreted to water by bacteria (Makowski and Wardas, 2001). Savino and Angeli (1985) used methylene blue-PACT to disinfect water samples contaminated with $E$. coli to acceptable levels for drinking. Bonnett et al., (2006) used a phthalocyanine immobilized on a polymeric membrane of chitosan as a model reactor of water disinfection. Regenerated cellulose impregnated with 5,10, 15, 20-tetrakis (1-methylpyridinium-4-yl) porphyrin tetra- $p$-tosylate showed photobactericidal activity against $S$. aureus, E. coli, Proteus vulgaris and Bacillus subtilis. Krouit et al. in 2006 showed efficient photoinactivation of Gram-positive and Gram-negative bacterial strains by cellulose films with immobilized porphyrin derivatives. It has got vast potential for application in aquaculture system, namely for use in water disinfection plants (Costa et al., 2008; Alves et al., 2009; Alves et al., 2008) and in fish-farming plants (Magaraggia et al., 2006; Arrojado et al., 2011). Costa et al. (2008) observed complete inactivation of viruses using a low light intensity concluding this methodology to be usefull even on cloudy days and during winter, opening the possibility to develope new technologies for wastewater treatment.

Antiviral photoinactivation: Viral photoinactivation appears to be different for enveloped and nonenveloped viruses. Several viral components, including nucleic acids and lipid-rich envelopes, are potential targets for photodynamic attack. However, it has been shown that enveloped viruses are significantly more sensitive to photodynamic destruction than nonenveloped viruses (Wainwright, 2004; Egyeki et al., 2003; Demidova and Hamblin, 2005). It is supposed that the lipids and proteins in the envelope act as photosensitizer binding-sites and viruses can be inactivated due to damages caused in their protein molecules (Egyeki et al., 2003). Porphyrins are demonstrated to have effective virucidal effect in vitro, apparently causing photodamage to the viral envelope (Wainwright, 1998). It is more likely that positively charged photosensitizers cause nucleic acid damage (oxidation of guanosine residues), whereas anionic photosensitizers act against the viral envelope (Lukšiene, 2005). Aminolipids and peptides in the viral envelope are potential targets, leading to the inactivation of membrane enzymes and receptors, whereas lipid peroxidation is detrimental to membrane integrity, leading to sudden loss of fluidity due to increased membrane permeability (Lukšiene, 2005). For nonenveloped viruses, the photoinactivation effects depend mainly on damages in the protein capsid and/or loosening of protein-DNA interaction (Egyeki et al., 2003). So far, photodynamic inactivation has been proven to be a powerful method for inactivating enveloped viruses, such as murine retroviral vectors (Ben-Hur et al., 1992), human immunodeficiency viruses (HIV-1 and -2) (Schagen et al., 1999; Vzorov et al., 2002), herpes simplex viruses (Silva et al., 2005; Tome et al., 2007), hepatitis-B (Wagner et al., 2001) and vesicular stomatitis virus (Horowitz et al., 1991) and also for the inactivation of nonenveloped viruses, like the adenovirus (Schagen et al., 1999), hepatitis A virus (Casteel et al., 2004), human papilloma virus (Wainwight, 2004) and T7 (Egyeki et al., 2003), lambda (Kasturi and Plaz, 1992) and MS2 (Casteel et al., 2004).

Antifungal photoinactivation: Fungi are much more complex targets than bacteria. For example, yeasts, which constitute a large group of rather disparate eukaryotic organisms, are enveloped by a thick external wall composed of a mixture of glucan, mannan, chitin and lipoproteins and separated from the plasma membrane by a periplasmic space. The phenothiaziniums, such as TBO and MB are known to localize in the plasma membrane of yeasts. Although phenothiazin dyes have traditionally been used more in the aPDT of fungi (Donnelly et al., 2008; Gonzales et al., 2010) porphyrin compounds have been successfully tested in the inactivation of yeasts (Carre et al., 1999; Oriel and Nitzan, 2010), dermatophytes (Donnelly et al., 2005; Smijs et al., 2007), conidia- forming fungi (Friedberg et al., 2001; Luksiene et al., 2004) and fungal fish pathogens (Magaraggia et al., 2006). Micromolar concentration of a porphyrin analogue is reported to promote the cure of saprolegniosis in trout farming pools containing Saprolegnia infected fish without causing perilesional damage of the fish (Magaraggia et al., 2006).

Anti-parasitic photoinactivation: Clinically successful photodynamic inactivation of Leishmania $s p$. (Morgenthaler et al., 2008) is reported where ALA and analogues, porphyrins of natural and synthetic type and other porphyrin related compounds are employed as PS resulting in treatment of cutaneous leishmaniasis (Latorre-Esteves et al., 2010). ALA has also been reported to be used in vitro for the inactivation of Plasmodium falciparum (Smith and Kain, 2004). Extensive photodamage of Colpoda inflata cysts, previously loaded with meso-tetrakis (1-methylpyridinium-4-yl) porphyrin tet- ratosylate (20a) and analogues was observed upon visible light irradiation (Kassab et al., 
2002). The same tetracationic porphyrin 20a, upon irradiation with white light, could successfully inactivate eggs of the helminths Ascaris lumbricoides and Taenia sp. (Alouini and Jemli, 2001).

Biofilm photoinactivation: Microbial biofilm cells are highly resistent to antibiotics and other antimicrobial treatments due to their distinct gene expression patterns, phenotypic variations in enzymic activity, cell wall composition and surface structure. It has been demonstrated that aPDT using MB as a PS is effective against $S$. mutans and $S$. aureus biofilms (Pereira et al., 2010).

\section{Conclusion}

Although there are only few studies done on aPDT in aquaculture systems, preliminary results indicate that this technology has a high potential to disinfect aquaculture waters. The effective inactivation of microorganisms, the improbable development of photoresistant strains, and the possibility of irradiating fishfarming waters in the presence of immobilized PS using solar light, suggest that aPDT can be considered an alternative technology to disinfect aquaculture waters. Low-cost visible light source is most preferred light source and free and immobilized PS represents a promising alternative to this kind of treatment since it allows the recovery and future re-utilization of the photosensitizer. This obviously turns it an easily applicable, less expensive and an environmentally safe technology. aPDT can be considered as a new approach to control fish infections in aquaculture systems, but the process is clearly more difficult to inactivate the complex natural bacterial communities of aquaculture waters than pure cultures of bacteria isolated from aquaculture systems.

\section{REFERENCES}

Almeida, A., Ângela, C., Newton, G., Alves, C.M., Costa, E., Liliana and Faustino, Maria, A.F. (2009). Phage therapy and photodynamic therapy: low environmental impact approaches to inactivate microorganisms in fish farming plants. Marine Drugs, 7: 268-313.

Agarwal, M.L., Clay, M.E., Harvey, E.J., Evans, H.H., Antunez, A.R., Oleinick, N.L. (1991). Photodynamic therapy induces rapid cell death by apoptosis in L5178Y mouse lymphoma cells. Cancer Res. 51 : 5993-6.

Akilov, O.E., Kosaka, S., O'Riordan, K., and Hasan, T. (2007). Photodynamic therapy for cutaneous leishmaniasis: the effectiveness of topical phenothiaziniums in parasite eradication and Th1 immune response stimulation. Exp. Dermatol. $16: 651$.

Alexandra, B. Ormond and Harold, S. Freeman. (2013). Dye Sensitizers for Photodynamic Therapy. Materials. 6 : 817-840.

Alouini, Z. and Jemli, M. (2001). Destruction of helminth eggs by photosensitized porphyrin. Journal of Environmental Monitoring. 3: 548-551.

Al-Rawahi, G.N.; Reynolds, S.; Porter, S.D.; Forrester, L.; Kishi, L.; Chong, T.; Bowie, W.R.; Doyle, P.W. (2008). Community-associated CMRSA-10 (USA-300) is the predominant strain among methicillin- resistant Staphylococcus aureus strains causing skin and soft tissue infections in patients presenting to the emergency department of a canadian tertiary care hospital. $J$. Emerg. Med.

Alves, E., Carvalho, C.M.B., Tome, J.P.C., Faustino, M.A.F., Neves, M., Tome, A.C., Cavaleiro, J.A.S., Cunha, Mendo A. S. (2008). Adelaide, Photodynamic inactivation of recombinant bioluminescent Escherichia coli by cationic porphyrins under artificial and solar irradiation. J. Ind. Microbiol. Biotechnol. 35 : 1447-1454.

Alves, E., Costa, L., Carvalho, C. Faustino, M.A.F., Neves, M.G.P.M.S., Tome, A.C., Cavaleiro, J.A.S., Cunha, A. and Almeida, A. (2009). Charge effect on the photoinactivation of Gram-negative and Gram-positive bacteria by cationic meso-substituted porphyrins. BMC Microbiol. 9 : 216- 221.

Alves, E., Maria, F., A. F., Tome, Joa o P. C., Maria, Neves, G..M.S., Augusto, C., Tome ., Cavaleiro, Jose, A. S., Cunha, A., Newton, G. C., Adelaide, A. (2011). Photodynamic Antimicrobial Chemotherapy in Aquaculture: Photoinactivation Studies of Vibrio fischeri. PLOS ONE. 6(6): 20970.

Arrojado, C., Pereira,C., Jo ao P. C., Maria,T., Faustino, A.F., Maria, Neves, G.P.M.S., Augusto, C. Tome'., Jose,' A. S., Cavaleiro, Cunha, A., Calado, R., Gomes, N. and Almeida, A. (2011). Applicability of photodynamic antimicrobial chemotherapy as an alternative to inactivate fish pathogenic bacteria in aquaculture systems. Photochem. Photobiol. Sci. 10 : 1691-1700.

Ashok, A., Arshad, E., Jasmin, C., Somnath,S. P., Bright Singh, I.S.,Mohandas, A. and Anas, A. (2012). Reducing Vibrio load in Artemia nauplii using antimicrobial photodynamic therapy: a promising strategy to reduce antibiotic application in shrimp larviculture. Microbial Biotechnology. 5(1): 59-68.

Baker, K.S. and Smith, R.C.(1982). The role of solar radiation in marine ecosystems, ed. J. Calkins, Plenum Press, New York, p. 233.

Ben-Hur, E., Hoeben, R.C., Van Ormondt, H., Dubbelman, T.M. and Van Steveninck, J. (1992). Photodynamic inactivation of retroviruses by phthalocyanines: the effects of sulphonation, metal ligand and fluoride. Journal of Photochemistry and Photobiology B: Biology. $13: 145-152$.

Benov, L. (2014). Photodynamic therapy: current status and future directions. Med Princ Pract. 14 : 1011-7571.

Bertoloni, G., Zambotto, F. L. Conventi, Reddi, E. and Jori, G. (1987). Role of specific cellular targets in the hematoporphyrin-sensitized photoinactivation of microbial- cells, Photochem. Photobiol. 46: 695.

Bezman, S.A., Burtis, P.A., Izod, T.P., Thayer, M.A. (1978). Photodynamic inactivation of E. coli by rose bengal immobilized on polystyrene beads. Photochem. Photobiol. $28: 325-329$.

Bonnett, R. (2000). Chemical aspects of photodynamic therapy, Gordon and Breach Science Publishers, Amsterdam.

Bonnett, R., Krysteva, M.A., Lalov, I.G. and Artarsky, S.V. (2006). Water disinfection using photosensitizers immobilized on chitosan. Water Res. $40: 1269$.

Capella, M.A. and Capella, L.S. (2003). A light in multidrug resistance: photodynamic treatment of multidrugresistant tumors. Journal of Biomedical Science. 10(4) : 
361-366.

Carre ,V., Gaud, O., Sylvain, I., Bourdon, O., Spiro, M., Blais, J., Granet, R., Krausz, P. and Guilloton,M. (1999). Fungicidal properties of mesoarylglycosylporphyrins: Influence of sugar substituents on photoinduced damage in the yeast Saccharomyces cerevisiae. J. Photochem. Photobiol. 48 : 57.

Carvalho, C.M.B., J.P.C. Tome', M.A.F. Faustino, M.G.P.M.S. Neves, A.C. Tome' , J.A.S. Costa, Costa, Cavaleiro, L., Alves, E. A., Oliveira, A ., Cunha and Almeida, A. (2009). Antimicrobial photodynamic activity of porphyrin derivatives: potential application on medical and water disinfection, J. Porphyrins Phthalocyanines. $13: 574$.

Casteel, M.J., Jayaraj, K., Gold, A., Ball, L.M., Sobsey, M.D.(2004). Photoinactivation of hepatitis A virus by synthetic porphyrins. Photochem. Photobiol. 80 : 294300.

Chen-Collins, A., Dixon, D., Vzorov, A., Marzilli, L., and Compans, R. (2003). Prevention of poxvirus infection by tetrapyrroles. BMC Infect. Dis. 3: 9.

Cheng, Y., Samia, A.C., Meyers, J.D.P., Panagopoulos, I., Fei, B., Burda, C. (2008). Highly efficient drug delivery with gold nanoparticle vectors for in vivo photodynamic therapy of cancer. J Am Chem Soc. 130 : 10643-7.

Christensen, T., Volden, G., Moan, J., Sandquist, T. (1982). Release of lysosomal enzymes and lactate dehydrogenase due to hematoporphyrin derivative and light irradiation of NHIK 3025 cells in vitro. Ann Clin Res. 14 : 46-52.

Costa, L., Alves, E., Carvalho, C.M.B., Tome, J.P.C., Faustino, M.A.F., Neves, M.G.P.M.S., Tome , A.C., Cavaleiro, J.A.S. Cunha, A. and Almeida, A. (2008). Sewage bacter-iophage photoinactivation by cationic porphyrins: a study of charge effect. Photochem. Photobiol. Sci., 7: 415.

Davies, C.L., Western, A., Lindmo, T., Moan, J. (1986). Changes in antigens expression on human FME melanoma cells after exposure to photoactivated hematoporphyrin derivatives. Cancer Res., 46 : 6068-72.

De Rosa, M.C.; Crutchley, R.J. (2002). Photosensitized singlet oxygen and its applications. Coord. Chem. Rev. $233: 351-371$.

Defoirdt, T., Boon, N., Sorgeloos, P., Verstraete, W. and Bossier, P., (2007). Alternatives to antibiotics to control bacterial infections: luminescent vibriosis in aquaculture as an example, Trends Biotechnol. 25: 472-479.

Demidova,T.N., Hamblin, M.R. (2005). Effect of cellphotosensitizer binding and cell density on microbial photoinactivation. Antimicrobial Agents and Chemotherapy. $49: 2329-2335$.

Dobson, J.; Wilson, M. (1992). Sensitization of oral bacteria in biofilms to killing by light from a low-power laser. Arch. Oral. Biol. 37(11): 883-887.

Donnelly, R.F., Mccarron, P.A. and Tunney, M.M. (2008). Antifungal photodynamic Therapy. Microbiol. Res. $163: 1$.

Donnelly, R.F., McCarron, P.A., Lightowler, J.M. and Woolfson, A.D. (2005). Bioadhesive patch-based delivery of 5-aminolevulinic acid to the nail for photodynamic therapy of onychomycosis. J. Controlled Release. $103: 381$.

Durantini, E.N. (2006). Photodynamic inactivation of bacteria, Curr. Bioact. Compd. 2: 127.

Egyeki, A., Turoczy, G., Majer, Z., Toth, K., Fekete, A., Maillard, P. and Csik, G. (2003). Photosensitized inactivation of $\mathrm{T} 7$ phage as surrogate of non-enveloped DNA viruses: efficiency and mechanism of action. Biochim. Biophys. Acta. 16(24) : 115.

Friedberg, J.S., Skema, C., Baum, E.D., Burdick, J., Vinogradov, S.A., Wilson, D.F., Horan, A.D. and Nachamkin, I. (2001). In vitro effects of photodynamic therapy on Aspergillus fumigates. J. Antimicrob. Chemother. $48: 105$.

Ganz, R., Viveiros, J., Ahmad, A., Ahmadi, A., Khalil, A., Tolkoff, M., Nishioka, N. and Hamblin, M. (2005). Helicobacter pylori in patients can be killed by visible light. Lasers Surg. Med. 36 : 260-268.

Gibson, S.L., Murant, R.S., Hilf, R. (1988). Photosensitizing effects of hematoporphyrin derivative and Photofrin II on the plasma membrane enzymes 58-nucleotidase, $\mathrm{Na}+$ $\mathrm{K}+-\mathrm{ATPase}$, and $\mathrm{Mg} 2+-\mathrm{ATPase}$ in R3230AC rat mammary adenocarcinomas. Cancer Res. 48 : 3360-6.

Gonzales, F.P., Da Silva, S.H., Roberts, D.W. and Braga, G.U. (2010). Photodynamic inactivation of conidia of the fungi Metarhizium anisopliae and Aspergillus nidulans with methylene blue and toluidine blue. Photochem. Photobiol. 86 : 653.

Hamblin, M.R. and Hasan, T. (2004). Photodynamic therapy: A new antimicrobial approach to infectious disease. Photochem. Photobiol. Sci. 3 : 436-450.

Hone, D.C., Walker, P.I., Evans-Gowing, R., FitzGerald, S., Beeby, A., Chambrier, I. (2002). Generation of cytotoxic singlet oxygen via phthalocyanine-stabilized gold nanoparticles: a potential delivery vehicle for photodynamic therapy. Langmuir. 18: 2985-7.

Horowitz, B., Williams, B., Rywkin, S., Prince, A.M., Pascual, D., Geacintov, N., Valinsky, J. (1991). Inactivation of viruses in blood with aluminium phthalocyanine derivatives. Transfusion. 31: 102-108.

Jemli, M. Alouini, Z. Sabbahi, S. and Gueddari, M. (2002). Destruction of fecal bacteria in wastewater by three photosensitizers. J. Environ. Monit. $4: 511$.

Joshi, P.G., Joshi, K., Mishra, S., Joshi, N.B. (1994). Ca $\mathrm{Ca}^{2+}$ influx induced by photodynamic action in human cerebral glioma (U-87 MG) cells: possible involvement of a calcium channel. Photochem Photobiol. 60 : 244-248.

Jui-Teng, Lin. (2014). Analysis on the efficacy of photodynamic antimicrobial chemotherapy in aquaculture systems. International Journal of Latest Research in Science and Technology. 3(4) : 37-39.

Kassab, K., Amor,T., Jori, G., and Coppellotti, O. (2002). Photosensitization of Colpoda inflata cysts by mesosubstituted cationic porphyrins. Photochem. Photobiol. Sci. $1: 560$.

Kassab, K., Dei, D., Roncucci, G., Jori, G. and Coppellotti, O. (2003). Phthalocyanine- photosensitized inactivation of a pathogenic protozoan, Acanthamoeba palestinensis, Photochem. Photobiol. Sci. 2: 668.

Kasturi, C. and Platz, M.S. (1992). Inactivation of lambda phage with $658 \mathrm{~nm}$ light using DNA binding porphyrin sensitizer. Photochemistry and Photobiology. 56 : 427429.

Kessel, D., Woodburn, K., Henderson, B.W., Chang, C.K. (1995). Sites of photodamage in vivo and in vitro by a cationic porphyrin. Photochem Photobiol. 62 : 875-881.

Kim, S.Y., Kwon, O.J. and Park, J.W. (2001). Inactivation of catalase and superoxide dis- mutase by singlet oxygen derived from photoactivated dye. Biochimie. 83: 437.

Kluck, R.M., Martin, S.J., Hoffman, B.M., Zhou, J.S., Green, D.R., Newmeyer, D.D. (1997) Cytochrome c activation 
of CPP32-like proteolysis plays a critical role in a Xenopus cell-free apoptosis system. EMBO J. 16 : 4639-49.

Konan, Y.N., Berton, M., Gurny, R., Allemann, E. (2003). Enhanced photodynamic activity of meso-tetra(4hydroxyphenyl)porphyrin by incorporation into sub-200 nm nanoparticles. Eur J Pharm Sci. 18(3-4): 241-249.

Konig, K., Teschke, M., Sigusch, B., Glockmann, E., Eick, S., and Pfister, W. (2000). Red light kills bacteria via photodynamic action. Cell. Mol. Biol. (Noisy-le-Grand, France) $46: 1297$.

Kosaka, S., Akilov, O., ORiordan, K. and Hasan, T. (2007). A mechanistic study of delta- aminolevulinic acid-based photodynamic therapy for cutaneous leishmaniasis, $J$. Invest. Dermatol. 127 : 1546.

Krouit, M., Granet, R., Branland, P., Verneuil, B., Krausz, P. (2006). New photoantimicrobial films composed of porphyrinated lipophilic cellulose esters. Bioorganic \& Medicinal Chemistry Letters. 16 : 1651-1655.

Latorre-Esteves, E., Akilov, O.E., Rai, P., Beverley, S.M. and Hasan,T. (2010). Monitoring the efficacy of antimicrobial photodynamic therapy in a murine model of cutaneous leishmaniasis using L. major expressing GFP. Biophotonics. $3: 328$.

Lazzeri, D., Rovera, M., Pascual, L., Durantini, E. N. (2004). Photodynamic studies and photoinactivation of $E S$ cherichia coli using meso-substituted cationic porphyrin derivatives with asymmetric charge distribution. Photochemistry and Photobiology. 80: 286-293.

Lukšiene, Z. (2005). New approach to inactivation of harmful and pathogenic microorganisms by photosensitization. Food Technology and Biotechnology. 43 : 411418.

Luksiene, Z., Peciulyte, D. and Lugauskas, A. (2004). Inactivation of fungi in vitro by photosensitization: preliminary results. Ann. Agr. Env. Med.: AAEM. $11: 215$

Maclean, M., MacGregor, S., Anderson J.G. and Woolsey, G.A. (2008). The role of oxygen in the visible-light inactivation of Staphylococcus aureus. J. Photochem. Photobiol., B . 92: 180

Magaraggia, M., Faccenda, F., Gandolfi, A. and Jori, G. (2006). Treatment of microbiologically polluted aquaculture waters by a novel photochemical technique of potentially low environmental impact. J. Environ. Monitor. $8: 923$.

Maisch, T.; Szeimies, R.M.; Jori, G.; Abels, C. (2004). Antibacterial photodynamic therapy in dermatology. Photochem. Photobiol. Sci. 3(10): 907-917.

Makowski, A. and Wardas, W. (2001). Photocatalytic degradation of toxins secreted to water by cyanobacteria and unicellular algae and photocatalytic degradation of the cells of elected micro-organisms. Curr Top Biophys. $25: 19-25$.

Menezes, S.; Capella, M.A.; Caldas, L.R. (1990). Photodynamic action of methylene blue: repair and mutation in Escherichia coli. J. Photochem. Photobiol. B. 5 : 505-517.

Merchat, M., Bertolini, G., Giacomini, P., Villanueva, A., Jori, G. (1996). Meso-substituted cationic porphyrins as efficient photosensitizers of gram-positive and gramnegative bacteria. J. Photochem. Photobiol. B. 32(3): 153-7.

Mettath, S., Munson, B.R. and Pandey, R.K. (1999). DNA interaction and photocleavage properties of porphyrins containing cationic substituents at the peripheral position. Bioconjug. Chem. 10: 94.

Meyer, F.P. (1991). Aquaculture disease and health manage- ment. J. Anim. Sci. $69:$ 4201-4208.

Milson, C.E., Wilson, M., Macrobert, A.J., Bedwell, J. and Bown, S.G. (1996). The killing of Helicobacter pylori by low-power laser light in the presence of a photosensitiser. J. Med. Microbiol. $44: 245$.

Minnock, A.; Vernon, D.I.; Schofield, J.; Griffiths, J.; Parish, J.H.; Brown, S.T. (1996). Photoinactivation of bacteria. Use of a cationic watersoluble zinc phthalocyanine to photoinactivate both gram-negative and gram-positive bacteria. J. Photochem. Photobiol. B. 32(3) : 159-164.

Moan, J. and Berg, K. (1991). The photodegradation of porphyrins in cells can be used to estimate the lifetime of singlet oxygen. Photochem Photobiol. 53 : 549-553.

Moan, J., Christensen, T. (1981). Cellular uptake and photodynamic effect of hematoporphyrin. Photobiochem Photobiophys. 2 : 291-9.

Moan, J., McGhie, J., Jacobsen, P.B. (1983). Photodynamic effects on cells in vitro exposed to hematoporphyrin derivative and light. Photochem Photobiol. 37 : 599604.

Moan, J., Pettersen, E.O., Christensen, T. (1979). The mechanism of photodynamic inactivation of human cells in vitro in the presence of haematoporphyrin. $\mathrm{Br} J$ Cancer. $39: 398-407$.

Morgenthaler, J.B., Peters, S.J., Ceden o,D.L., Constantino, M.H., Edwards, K.A., Kamowski, E.M., Passini,J.C., Butkus, B.E., Young, A.M., Lash, T.D. and Jones, M.A. (2008). Carbaporphyrin ketals as potential agents for a new photodynamic therapy treatment of leishmaniasis. Bioorg. Med. Chem. 16: 7033 .

Ohulchanskyy, T.Y., Roy, I., Goswami, L.N., Chen, Y., Bergey, E.J., Pandey, R.K. (2007). Organically modified silica nanoparticles with covalently incorporated photosensitizer for photodynamic therapy of cancer. Nano Lett. 7 : 2835-42.

Oriel, S. and Nitzan, Y. (2010). Photoinactivation of Candida albicans by its own endogenous porphyrins. Curr. Microbiol. $60: 117$.

O'Riordan, K.; Akilov, O.E.; Hasan, T. (2005). The potential for photodynamic therapy in the treatment of localized infections. Photodiagnosis Photodyn. Ther. 2 : 247-262.

Peng, Q., Moan, J., Nesland, J.M. (1996). Correlation of subcellular and intratumoral photosensitizer localization with ultrastructural features after photodynamic therapy. Ultrastruct Pathol. 20 : 109-129.

Pereira, C.A., Romeiro, R.L., Costa, A.C., Machado, A.K., Junqueira, J.C., Jorge, A.O.(2010). Susceptibility of Candida albicans, Staphylococcus aureus, and Streptococcus mutans biofilms to photodynamic inactivation: an in vitro study. Lasers Med. 26(3): 341348.

Reddi, E.; Ceccon, M.; Valduga, G.; Jori, G.; Bommer, J.C.; Elisei, F.; Latterini, L.; Mazzucato, U. (2002). Photophysical properties and antibacterial activity of meso-substituted cationic porphyrins. Photochem. Photobiol. 75(5) : 462-470.

Reyftman, J.B., Santus, R., Morliere, P., Kohan, E. (1986). Fluorescent products formed by reaction of amino acids and spermidine with lipid peroxides produced by porphyrin photosensitization in ionic micelles. Photobiochem Photobiophys. 11 : 197-208.

Roy, I., Ohulchanskyy, T.Y., Pudavar, H.E., Bergey, E.J., Oseroff, A.R., Morgan, J. (2003). Ceramic-based nanoparticles entrapping water-insoluble photosensitizing anticancer drugs: a novel drug-carrier system for 
photodynamic therapy. J Am Chem Soc. 125 : 7860-5.

Savino, A., Angeli, G. (1985). Photodynamic inactivation of E. coli by immobilized or coated dyes on insoluble supports. Water Res. 19 :1465-1469.

Schafer, M., Schmitz C. and Horneck, G. (1998). High sensitivity of Deinococcus radio- durans to photodynamically-produced singlet oxygen. Int. J. Radiat. Biol. 74: 249.

Schagen, F.H.E., Moor, A.C.E., Cheong, S.C., Cramer, S.J., Ormondt, H., Eb, A.J., Dubbelman ,T.M.A.R, Hoeben, R.C. (1999). Photodynamic treatment of adenoviral vectors with visible light: an easy and convenient method for viral inactivation. Gene Therapy. $6: 873$ 881.

Schleier, P., Hyckel, P., Berndt,A., Bode,H.P., Albrecht,V., Hindermann,W., Kosmehl,H., Zenk,H. and Schumann, D. (2004). Photodynamic therapy of virus-associated epithelial tumours of the face in organ transplant recipients. J. Cancer Res. Clin. Oncol. 130 : 279-287.

Shao, Z. (2001). Aquaculture pharmaceuticals and biological: current perspectives and future, Adv. Drug Delivery Rev. $50: 229-243$.

Silva, E.M.P., Giuntini, F., Faustino, M.A.F., Tome, J.P.C., Neves, M., Tome, A.C., Silva, A.M.S., SantanaMarques, M.G., Ferrer-Correia, A.J., Cavaleiro, J.A.S., Caeiro, M.F., Duarte, R.R., Tavares, S.A.P., Pegado, I.N., d'Almeida, B., De Matos, A.P.A., Valdeira, M.L. (2005). Synthesis of cationic beta-vinyl substituted meso-tetraphenylporphyrins and their in vitro activity against herpes simplex virus type 1 . Bioorganic \&. Medicinal Chemistry Letters. 15 : 3333-3337.

Smijs, T., Bouwstra, J., Schuitmaker, H., Talebi, M. and Pavel, S. (2007). A novel ex vivo skin model to study the susceptibility of the dermatophyte Trichophyton rubrum to photodynamic treatment in different growth phases. J. Antimicrob. Chemother. $59: 433$.

Smith, T. and Kain, K. (2004). Inactivation of Plasmodium falciparum by photodynamic excitation of heme cycle intermediates derived from aminolevulinic acid. $J$. Infect. Dis. 190: 184.

Specht, K.G., Rodgers, M.A. (1990). Depolarization of mouse myeloma cell membranes during photodynamic action. Photochem Photobiol. $51: 319-324$.

Tagmatarchis, N.; Shinohara, H. (2001). Fullerenes in medicinal chemistry and their biological applications. Mini. Rev. Med. Chem. 1(4): 339-348.

Tang, H.M., Hamblin, M.R. and Yow, C.M. (2007). A comparative in vitro photo- inactivation study of clinical isolates of multidrug-resistant pathogens. J. Infect. Chemother. $13: 87$.

Tanielian, C.; Schweitzer, C.; Mechin, R.; Wolff, C. (2001). Quantum yield of singlet oxygen production by monomeric and aggregated forms of hematoporphyrin derivative. Free Radic. Biol. Med. 30(2): 208-212.

Thomas, J.P., Girotti, A.W. (1989). Role of lipid peroxidation in hematoporphyrin derivative-sensitized photokilling of tumor cells: protective effects of glutathione peroxidase. Cancer Res. 49 : 1682-6.

Tome, J.P.C., Silva, E.M.P., Pereira, A., Alonso, C.M.A., Faustino, M.A.F., Neves, M., Tome, A.C., Cavaleiro, J.A.S., Tavares, S.A.P., Duarte, R.R., Caeiro, M.F.,
Valdeira, M.F. (2007). Synthesis of neutral and cationic tripyridylporphyrin-D-galactose conjugates and tha photoinactivation of HSV-1. Bioorg. Med. Chem. 15 : 4705-4713.

Toranzo, A.E., Magari nos, B. and Romalde, J.L. (2005). A review of the main bacterial fish diseases in mariculture systems. Aquaculture. $246: 37-61$.

Volden, G., Christensen, T., Moan, J. (1981). Photodynamic membrane damage of hematoporphyrin derivativetreated NHIK 3025 cells in vitro. Photobiochem Photobiophys. 3 : 105-111.

Vzorov, A.N., Dixon, D.W., Trommel, J.S., Marzilli, L.G., Compans, R.W. (2002). Inactivation of human immunodeficiency virus type 1 by porphyrins. Antimicrobial Agents and Chemotherapy. $46: 3917-3925$.

Wagner, S.J., Skipchenko, A., Pugh, J.C., Suchmann,D.B., Ijaz, M.K. (2001). Duck hepatitis B photoinactivation by dimethylmethylene blue in RBC suspensions. Transfusion. 41: 1154-1158.

Wainwright, M. (1998). Photodynamic antimicrobial chemotherapy (PACT). J. Antimicrobial Chemotherapy. 42 : 13-28.

Wainwright, M. (2000). Methylene blue derivatives - suitable photoantimicrobials for blood products disinfection. International Journal of Antimicrobial Agents. $16: 381-394$.

Wainwright, M. (2004). Photoinactivation of viruses. Photochemical and Photobiological Sciences. 3: 406-411.

Wainwright, M. and Crossley, K.B. (2004). Photosensitising agents - circumventing resistance and breaking down biofilms: a review. Int. Biodeter. Biodegr. 53: 119.

Wainwright, M. (2007). Natural Product Photoantimicrobials. Current Bioactive Compounds. 3(4) : 252-261.

Wang, S., Gao, R., Zhou, F., Selke, M. (2004). Nanomaterials and singlet oxygen photosensitizers: potential applications in photodynamic therapy. Journal of Materials Chemistry. 14: 487-493.

Webber, J., Luo, Y., Crilly, R., Fromm, D., Kessel, D. (1996). An apoptotic response to photodynamic therapy with endogenous protoporphyrin in vivo. J Photochem Photobiol B. 35 : 209-211.

Wilder-Smith, C., Wilder-Smith, P., Grosjean, P., Van Den Bergh, H., Woodtli, A., Monnier, Dorta, P., G., Meister, F., and Wagnieres, G. ( 2002). Photoeradication of Helicobacter pylori using 5-aminolevulinic acid: preliminary human studies. Lasers Surg. Med. $31: 18$.

Wolfsen, H. and Wang, K. (1993). Tolerance of normal swine gastric epithelium to pho- todynamic therapy using topically applied haematoporphyrin derivative. Lasers. Surg. Med. 5 : 18.

Zaidi, S.I., Oleinick, N.L., Zaim, M.T., Mukhtar, H. (1993). Apoptosis during photodynamic therapy-induced ablation of RIF-1 tumors in $\mathrm{C} 3 \mathrm{H}$ mice: electron microscopic, histopathologic and biochemical evidence. Photochem Photobiol. 58 : 771-776.

Zupan, K., Egyeki, M., Toth, K., Fekete, A., Herenyi, L., Modos K. and Csik, G. (2008). Comparison of the efficiency and the specificity of DNA-bound and free cationic porphyrin in photodynamic virus inactivation. J. Photochem. Photobiol. B. 90: 105. 